\title{
Front Matter: Volume 8244
}

, "Front Matter: Volume 8244," Proc. SPIE 8244, Laser-based Micro- and Nanopackaging and Assembly VI, 824401 (8 March 2012); doi: 10.1117/12.930884

SPIE. Event: SPIE LASE, 2012, San Francisco, California, United States 


\section{PROCEEDINGS OF SPIE}

\section{Laser-based Micro- and Nanopackaging and Assembly VI}

Friedrich G. Bachmann

Wilhelm Pfleging

Kunihiko Washio

Jun Amako

Willem Hoving

Yongfeng Lu

Editors

24-26 January 2012

San Francisco, California, United States

Sponsored and Published by

SPIE 
The papers included in this volume were part of the technical conference cited on the cover and title page. Papers were selected and subject to review by the editors and conference program committee. Some conference presentations may not be available for publication. The papers published in these proceedings reflect the work and thoughts of the authors and are published herein as submitted. The publisher is not responsible for the validity of the information or for any outcomes resulting from reliance thereon.

Please use the following format to cite material from this book:

Author(s), "Title of Paper," in Laser-based Micro- and Nanopackaging and Assembly VI, edited by Friedrich G. Bachmann, Wilhelm Pfleging, Kunihiko Washio, Jun Amako, Willem Hoving, Yongfeng Lu, Proceedings of SPIE Vol. 8244 (SPIE, Bellingham, WA, 2012) Article CID Number.

ISSN 0277-786X

ISBN 9780819488879

Published by

SPIE

P.O. Box 10, Bellingham, Washington 98227-0010 USA

Telephone +1 3606763290 (Pacific Time) · Fax +1 3606471445

SPIE.org

Copyright (C) 2012, Society of Photo-Optical Instrumentation Engineers

Copying of material in this book for internal or personal use, or for the internal or personal use of specific clients, beyond the fair use provisions granted by the U.S. Copyright Law is authorized by SPIE subject to payment of copying fees. The Transactional Reporting Service base fee for this volume is $\$ 18.00$ per article (or portion thereof), which should be paid directly to the Copyright Clearance Center (CCC), 222 Rosewood Drive, Danvers, MA 01923. Payment may also be made electronically through CCC Online at copyright.com. Other copying for republication, resale, advertising or promotion, or any form of systematic or multiple reproduction of any material in this book is prohibited except with permission in writing from the publisher. The CCC fee code is 0277-786X/12/\$18.00.

Printed in the United States of America.

Publication of record for individual papers is online in the SPIE Digital Library.

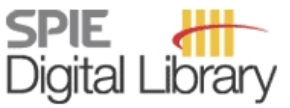

SPIEDigitalLibrary.org

Paper Numbering: Proceedings of SPIE follow an e-First publication model, with papers published first online and then in print and on CD-ROM. Papers are published as they are submitted and meet publication criteria. A unique, consistent, permanent citation identifier (CID) number is assigned to each article at the time of the first publication. Utilization of CIDs allows articles to be fully citable as soon as they are published online, and connects the same identifier to all online, print, and electronic versions of the publication. SPIE uses a six-digit CID article numbering system in which:

- The first four digits correspond to the SPIE volume number.

- The last two digits indicate publication order within the volume using a Base 36 numbering system employing both numerals and letters. These two-number sets start with $00,01,02,03,04$, $05,06,07,08,09,0 A, 0 B \ldots 0 Z$, followed by 10-1Z, 20-2Z, etc.

The CID number appears on each page of the manuscript. The complete citation is used on the first page, and an abbreviated version on subsequent pages. Numbers in the index correspond to the last two digits of the six-digit CID number. 


\section{Contents}

vii Conference Committee
ix Introduction

SESSION 1 WELDING, BONDING, BRAZING

824402 Welding of transparent materials with ultrashort laser pulses (Invited Paper) [8244-01]

S. Richter, S. Döring, F. Zimmermann, L. Lescieux, Friedrich-Schiller-Univ. Jena (Germany);

R. Eberhardt, Fraunhofer-Institut für Angewandte Optik und Feinmechanik (Germany);

S. Nolte, A. Tünnermann, Friedrich-Schiller-Univ. Jena (Germany) and Fraunhofer-Institut für Angewandte Optik und Feinmechanik (Germany)

824403 Direct welding of fused silica with femtosecond fiber laser [8244-02]

H. Huang, L.-M. Yang, J. Liu, PolarOnyx, Inc. (United States)

824404 Highly precise and robust packaging of optical components [8244-35]

M. Leers, M. Winzen, E. Liermann, H. Faidel, T. Westphalen, J. Miesner, J. Luttmann,

D. Hoffmann, Fraunhofer Institute for Laser Technology (Germany)

824406 End cap splicing of photonic crystal fibers with outstanding quality for high-power applications [8244-04]

S. Böhme, S. Fabian, T. Schreiber, R. Eberhardt, A. Tünnermann, Fraunhofer-Institut für

Angewandte Optik und Feinmechanik (Germany)

\section{SESSION 2 STRUCTURING AND MODIFICATION OF THIN FILMS}

824407 Amorphous Si crystallization by 405-nm GaN laser diodes for high-performance TFT applications: advantages of using 405-nm wavelength (Invited Paper) [8244-05]

K. Morimoto, N. Suzuki, Panasonic Corp. (Japan); X. Liu, Panasonic Boston Lab. (United

States); K. Samonji, K. Yamanaka, M. Yuri, Panasonic Corp. (Japan)

824408 Heat-induced structure formation in metal films generated by single ultrashort laser pulses [8244-06]

J. Koch, C. Unger, B. N. Chichkov, Laser Zentrum Hannover e.V. (Germany)

824409 Laser micromachining of organic LEDs [8244-08]

T. Petsch, J. Hänel, M. Clair, C. Scholz, 3D-Micromac AG (Germany)

8244 OA Analysis and characterization of the laser decal transfer process [8244-09]

S. A. Mathews, R. C. Y. Auyeung, A. Piqué, U.S. Naval Research Lab. (United States)

$8244 \mathrm{OB}$ Laser origami: a new technique for assembling 3D microstructures [8244-10]

A. Piqué, S. A. Mathews, N. A. Charipar, A. J. Birnbaum, U.S. Naval Research Lab. (United States) 
8244 OD Nano-structured surfaces by laser interference lithography and fs-laser direct writing as substrates for surface-enhanced Raman spectroscopy [8244-12]

L. Ben Mohammadi, N. Hundertmark, F. Kullmann, F. Fleissner, T. Klotzbücher, Institut für Mikrotechnik Mainz GmbH (Germany)

$8244 \mathrm{OE}$ In-situ diagnostics on fs-laser-induced modification of glasses for selective etching [8244-13]

M. Hermans, J. Gottmann, A. Schiffer, RWTH Aachen (Germany)

8244 OF Large area direct fabrication of periodic arrays using interference patterning [8244-14] A. F. Lasagni, Fraunhofer IWS Dresden (Germany); T. Roch, Fraunhofer IWS Dresden (Germany) and Technische Univ. Dresden (Germany); D. Langheinrich, M. Bieda, Fraunhofer IWS Dresden (Germany); H. Perez, Fraunhofer IWS Dresden (Germany) and Technische Univ. Dresden (Germany); A. Wetzig, Fraunhofer IWS Dresden (Germany); E. Beyer, Fraunhofer IWS Dresden (Germany) and Technische Univ. Dresden (Germany)

8244 OG Integration of a three-dimensional filter in a microfluidic chip for separation of microscale particles [8244-15]

N. Bellini, Istituto di Fotonica e Nanotecnologie, CNR, Politecnico di Milano (Italy); Y. Gu, Massachusetts Institute of Technology (United States); L. Amato, S. Eaton, G. Cerullo,

R. Osellame, Istituto di Fotonica e Nanotecnologie, CNR, Politecnico di Milano (Italy)

$8244 \mathrm{OH} \quad$ Laser-induced breakdown spectroscopy with improved spectral resolutions through the generation of high-temperature and low-density plasmas [8244-16]

X. N. He, Univ. of Nebraska-Lincoln (United States); L. B. Guo, Univ. of Nebraska-Lincoln (United States) and Wuhan National Lab. for Optoelectronics (China); Z. Q. Xie, X. Huang, W. Hu, Univ. of Nebraska-Lincoln (United States); X. Y. Zeng, Wuhan National Lab. for Optoelectronics (China); Y. F. Lu, Univ. of Nebraska-Lincoln (United States)

8244 Ol Enhancement of laser-induced breakdown spectroscopy signals using both a hemispherical cavity and a magnetic field [8244-17]

L. B. Guo, Univ. of Nebraska-Lincoln (United States) and Wuhan National Lab. for Optoelectronics (China); X. N. He, B. Y. Zhang, Univ. of Nebraska-Lincoln (United States);

C. M. Li, Univ. of Nebraska-Lincoln (United States) and Wuhan National Lab. for Optoelectronics (China); W. Hu, Y. S. Zhou, W. Xiong, Univ. of Nebraska-Lincoln (United States); X. Y. Zeng, Wuhan National Lab. for Optoelectronics (China); Y. F. Lu, Univ. of Nebraska-Lincoln (United States)

\section{SESSION 4 LASER MICRO-STRUCTURING AND MODIFICATION I}

$82440 \mathrm{~J}$ Laser structuring of metallic mold inserts by using $\mu \mathrm{s}$, ns, and ps-laser ablation (Invited Paper) [8244-18]

S. G. Scholz, A. Kolew, C. Griffiths, Cardiff Univ. (United Kingdom)

8244 OK Laser-chemical precision machining of micro forming tools at low laser powers [8244-19] S. Mehrafsun, Bremer Institut für angewandte Strahltechnik GmbH (Germany); P. Zhang, Bremer Institut für Messtechnik, Automatisierung und Qualitätswissenschaft (Germany); F. Vollertsen, Bremer Institut für angewandte Strahltechnik GmbH (Germany); G. Goch, Bremer Institut für Messtechnik, Automatisierung und Qualitätswissenschaft (Germany) 
$8244 \mathrm{OL} \quad$ Process limitations in microassembling using holographic optical tweezers [8244-21]

R. Ghadiri, Q. Guo, I. Yeoh, C. Esen, A. Ostendorf, Ruhr-Univ. Bochum (Germany)

\section{SESSION 5 LASER MICRO-STRUCTURING AND MODIFICATION II}

8244 ON Plastic optofluidic chip fabricated by femtosecond laser ablation [8244-23]

R. Martínez Vázquez, S. M. Eaton, G. Cerullo, R. Ramponi, R. Osellame, Istituto di Fotonica e Nanotecnologie, CNR, Politecnico di Milano (Italy)

824400 Control of element distribution in glass with femtosecond laser [8244-24]

M. Shimizu, M. Sakakura, M. Nishi, Y. Shimotsuma, K. Hirao, K. Miura, Kyoto Univ. (Japan)

8244 OP High-power picosecond laser with $400 \mathrm{~W}$ average power for large scale applications [8244-25]

K. Du, EdgeWave GmbH (Germany); S. Brüning, Schepers GmbH (Germany); A. Gillner, Fraunhofer-Institut für Lasertechnik (Germany)

$8244 \mathrm{OQ}$ Rotating optics for laser taper-drilling in research and production [8244-26]

D. Ashkenasi, T. Kaszemeikat, N. Mueller, M. Schmidt, Laser- und Medizin-Technologie GmbH, Berlin (Germany); H. J. Eichler, Laser- und Medizin-Technologie GmbH, Berlin (Germany) and Technische Univ. Berlin (Germany); M. Clair, T. Petsch, J. Hänel, M. Lasch, C. Scholz, 3D-Micromac AG (Germany)

\section{SESSION 6 BATTERIES}

8244 OR Laser cutting of graphite anodes for automotive lithium-ion secondary batteries: investigations in the edge geometry and heat-affected zone (Invited Paper) [8244-27] B. Schmieder, Manz AG (Germany)

8244 OS Laser-adjusted three-dimensional Li-Mn-O cathode architectures for secondary lithium-ion cells [8244-28]

J. Pröll, R. Kohler, M. Torge, M. Bruns, Karlsruhe Institute of Technology (Germany); M. Przybylski, ATL Lasertechnik GmbH (Germany); S. Ulrich, H. J. Seifert, Karlsruhe Institute of Technology (Germany); W. Pfleging, Karlsruhe Institute of Technology (Germany) and Karlsruhe Nano Micro Facility (Germany)

8244 OT Influence of laser-generated surface structures on electrochemical performance of lithium cobalt oxide [8244-29]

R. Kohler, J. Proell, S. Ulrich, Karlsruhe Institute of Technology (Germany); M. Przybylski, ATL Lasertechnik GmbH (Germany); H. J. Seifert, Karlsruhe Institute of Technology (Germany); W. Pfleging, Karlsruhe Institute of Technology (Germany) and Karlsruhe Nano Micro Facility (Germany)

8244 OU Transient thermal analysis and mechanical strength testing of pulsed laser welded ribbons to feedthru joints [8244-30]

Y. Lin, G. Jiang, Alfred E. Mann Foundation for Scientific Research (United States) 
SESSION 7 PHOTOVOLTAICS: JOINT SESSION WITH CONFERENCE 8243

$8244 \mathrm{OV}$ Laser sintering of Si and Ge nano- and microparticle films toward solar cells by solution process [8244-31]

A. Watanabe, Tohoku Univ. (Japan)

POSTER SESSION

8244 OX High-throughput process parallelization for laser surface modification on Si-solar cells: determination of the process window [8244-33]

V. Schütz, A. Horn, U. Stute, Laser Zentrum Hannover e.V. (Germany)

Author Index 


\title{
Conference Committee
}

\author{
Symposium Chairs
}

Friedhelm Dorsch, TRUMPF Werkzeugmaschinen GmbH + Co. KG (Germany)

Alberto Piqué, U.S. Naval Research Laboratory (United States)

Symposium Cochairs

Bo Gu, IPG Photonics Corporation (China)

Andreas Tünnermann, Friedrich-Schiller-Universität Jena (Germany)

Program Track Chairs

Henry Helvajian, The Aerospace Corporation (United States)

James S. Horwitz, U.S. Department of Energy (United States)

Conference Chairs

Friedrich G. Bachmann, LUMERA LASER GmbH (Germany)

Wilhelm Pfleging, Karlsruher Institute for Technology (Germany)

Kunihiko Washio, Paradigm Laser Research Ltd. (Japan)

Conference Cochairs

Jun Amako, Seiko Epson Corporation (Japan)

Willem Hoving, Avantes B.V. (Netherlands)

Yongfeng Lu, University of Nebraska-Lincoln (United States)

Program Committee

Craig B. Arnold, Princeton University (United States)

Francois Courvoisier, Université de Franche-Comté (France)

Ramona Eberhardt, Fraunhofer-Institut für Angewandte Optik und

Feinmechanik (Germany)

Bo Gu, IPG Photonics Corporation (China)

Duncan P. Hand, Heriot-Watt University (United Kingdom)

Minghui Hong, National University of Singapore (Singapore)

Lan Jiang, Beijing Institute of Technology (China)

Nam Seong Kim, EO Technics Company, Ltd. (Korea, Republic of)

Sonja M. Kittel, Robert Bosch GmbH (Germany)

Rainer Kling, ALPhANOV (Germany)

Udo Klotzbach, Fraunhofer IWS Dresden (Germany)

Thomas Klotzbücher, Institut für Mikrotechnik Mainz GmbH (Germany) 
Xinbing Liu, Panasonic Boston Laboratory (United States)

Marius Przybylski, ATL Lasertechnik GmbH (Germany)

Yasu Osako, Electro Scientific Industries, Inc. (United States)

Roberto Osellame, Istituto di Fotonica e Nanotecnologie, CNR,

Politecnico di Milano (Italy)

Andreas Ostendorf, Ruhr- Universität Bochum (Germany)

Alberto Piqué, U.S. Naval Research Laboratory (United States)

Razvan Stoian, Laboratoire Hubert Curien, CNRS, Université Jean Monnet Saint-Etienne (France)

Koji Sugioka, RIKEN (Japan)

Akira Watanabe, Tohoku University (Japan)

Xianfan Xu, Purdue University (United States)

\section{Session Chairs}

1 Welding, Bonding, Brazing

Friedrich G. Bachmann, LUMERA LASER GmbH (Germany)

2 Structuring and Modification of Thin Films

Kunihiko Washio, Paradigm Laser Research Ltd. (Japan)

3 Laser Nano-Structuring

Yongfeng Lu, University of Nebraska-Lincoln (United States)

$4 \quad$ Laser Micro-Structuring and Modification I

Udo Klotzbach, Fraunhofer IWS Dresden (Germany)

5 Laser Micro-Structuring and Modification II

Willem Hoving, Avantes B.V. (Netherlands)

$6 \quad$ Batteries

Wilhelm Pfleging, Karlsruher Institute for Technology (Germany)

7 Photovoltaics: Joint Session with Conference 8243

Rainer Kling, ALPhANOV (France) 


\section{Introduction}

This conference series was established in 2002, under the name "Laser-Based Packaging in Microelectronics and Photonics." In 2004, the conference was renamed as "Laser-Based Micro-Packaging." In 2007, the conference was again renamed, this time as "Laser-based Micro- and Nanopackaging and Assembly (LBMP)," to reflect the relevance of nanoscale structures.

The LBMP conference brings together scientists from academic institutions and industry in order to provide a platform for mutual and fruitful discussions on application-oriented, cutting-edge research fields. The scope of relevant applications covers the fabrication of electronic, photonic, mechanical, chemical, biological, bio-active, and bio-compatible devices including MEMS/bio-MEMS, MOEMS, and OLED. Because of the strong economical demand, laser material processing is playing increasingly important roles in areas covered by the LBMP conferences, along with new "green technologies" such as photovoltaic and advanced energy storage systems. Leading designs and applications are progressively based on micro- and nanosystem technologies because of their novel and significantly improved physical, chemical, and biological properties and phenomena. Advanced laser-based micro- and nanopackaging and assembly is strongly demanded by high-tech industries for specialized prototypes and high-throughput devices with micro- and nanostructures to realize electronic, photonic, mechanical, fluidic, chemical, and biological functionalities. However, the realization of such devices or functional prototypes imposes new challenges for patterning, packaging, and assembly. Economic aspects of production processes are a critical part of the applications. Only interdisciplinary approaches with strong association among researchers from industry and academic institutes can overcome the barriers for transferring new technologies at research stage to commercial products.

Miniaturization of the functional devices and systems significantly increases the complexity of their design and fabrication. Due to the continuous increase in complexity of device structures, processing needs for wide varieties of materials is leading to new applications and research fields but at the same time imposing new challenges for appropriate assembly and packaging technologies. The laser-induced modification of material properties on micro- or nanoscale becomes more and more important in some applications (e.g. photovoltaic) where undesired material and surface modifications such as chemical or heataffected structural changes must be avoided. Meanwhile, an increase in production costs or a significant change of established production lines can be limiting factors. Therefore, both, high-performance new products and innovations for high-efficiency/high-throughput manufacturing and assembly technologies are the focus of the conference. 
The conference LBMP-VI was held on 24-26 January 2012 as part of LASE at Photonics West in San Francisco, California. LBMP-VI comprised 32 presentations which were presented by speakers from France, UK, Italy, Japan, Russia, Germany, and the United States. Presentations represented a number of topics including: laser welding and joining, ultrafast laser, high-power GaN violet diode laser, advanced laser-assisted deposition and synthesis, laser micro- and nanostructuring and modification, micro- and nanomachining, batteries and thin films, direct-write processing and surface modification, and photovoltaics. The photovoltaics session was jointly organized with Conference 8243: Laser Applications in Microelectronic and Optoelectronic Manufacturing (LAMOM) $\mathrm{XVII.}$

We would like to express our deepest gratitude to the program committee members and the SPIE technical staff for their great efforts during the planning and organization of LBMP-VI. We would also like to thank the invited speakers and presenters of the contributed papers for their contribution to the success of the conference. All the manuscripts were peer-reviewed in order to publish highquality conference proceedings.

\author{
Friedel Bachmann \\ Wilhelm Pfleging \\ Kunihiko Washio \\ Jun Amako \\ Willem Hoving \\ Yongfeng Lu
}

